\title{
Demographic Characteristics of Population Ageing in Slovakia
}

I. Bartosovic (Ivan Bartosovic)', E. Zacharova (Eva Zacharova)', K. Zrubakova (Katarina Zrubakova)2, E. Gazikova (Elena Gazikova)4 , D. J. West (Daniel J. West)3, M. M. Costello (Michael M. Costello) ${ }^{3}$

Original Article

${ }^{1}$ St. Elizabeth University of Health and Social Work, Bratislava, SK

${ }^{2}$ Catholic University Ruzomberok, SK

${ }^{3}$ University of Scranton, Department of Health Administration and Human Resources, USA

${ }^{4}$ Constantine the Philosopher University in Nitra, Slovakia

\section{E-mail address:}

michael.costello@scranton.edu

\section{Reprint address:}

Michael M. Costello

University of Scranton

Department of Health Administration and Human Resources

Pennsylvania, USA

Suource: Clinical Social Work and Health Intervention

Pages: $7-14$

Volume: 8

Issue: 3

\section{Reviewers:}

Vlastimil Kozon

Allgemeines Krankenhaus - Medizinischer Universitätscampus Vienna, AU

Stefan Krajcik

Geriatric Department, Slovak Medical University, SK

\section{Key words:}

Demography, Crude birth rate, Mortality, Life expectancy, Healthy life years, Aging Index, Total dependency ratio, Active Aging Index.

\section{Publisher:}

International Society of Applied Preventive Medicine i-gap

CSWHI 2017; 8(3): 7 - 14; DOI 10.22359/cswhi_8_3_01 @ 2017 Clinical Social Work and Health Intervention

\section{Abstract:}

Population aging is a global process which is particularly marked mainly in developed countries, especially in Europe. From the point of view 
of gerontology and geriatrics the following characteristics are typical for the current demographic trend: persistently decreasing crude birth rate; stagnancy of mortality; increasing life expectancy; changes in the age structure; growth of the group of very old people; feminization of aging; changes in demographic indices. The phenomenon of "over-mortality" of men is confirmed by the fact that $79 \%$ of all deaths in 2015 in the age category from 30 to 34 years are deceases of men. According to the OECD, the age-standardized mortality rate for cardiovascular diseases and the age-standardized mortality rate for cancer (per 100,000 population), Slovakia is the worst among the countries of OECD and other compared countries. As for the life expectancy, Slovakia is on the bottom position among the countries of the European Union. In 2014, the healthy life years at birth in Slovakia were 55.5 years in men and 54.6 years in women. At present, $\mathbf{1 4 . 4 5 \%}$ of people in Slovakia are 65 years old or older. According to predictions, in 2060 every third inhabitant in Slovakia will be at least 65 years old. A very important demographic feature is also the growth of the group of "very old people", thus the so-called double aging. The "double aging" process means that more people are living longer while fewer children are born, resulting in an increase in the median age.

Population aging is a global process which is particularly marked mainly in developed countries, especially in Europe. In this regard, this situation is specific in Slovakia. As a result of very intensive population aging, within 40 years Slovakia will transform from a relatively young European country into one of the oldest countries in Europe (Vano, 2015). The following characteristics are typical for the demographic trend from the view of gerontology and geriatrics:

- persistently decreasing crude birth rate,

- stagnancy in mortality,

- increasing life expectancy,

- changes in the age structure,

- growing group of very old people,

- feminization of aging,

- changes in demographic indices (Hegyi et al., 2012).

\section{Persistently decreasing crude birth rate}

The crude birth rate is the number of live births occurring among the population of a given geographical area during a given year, per 1,000 mid-year total population of the given geographical area during the same year, thus expressed in per mille (Jurcova, 2005). In Slovakia, the crude birth rate was $\mathbf{1 0 . 3 \%}$. Since 2001 , this value has not changed notably $(9.5 \%$ in $2001,10.0 \%$ in $2004,10.0 \%$ in $2006,11.3 \%$ in 2009). However, one should notice that, e.g., in 1950 the crude rate birth was 28.79\% and in 1979 its value was 20.29\% (SU SR, 2016, Katusa et al., 2014).

\section{Stagnancy of mortality}

The crude death rate is the number of deaths occurring among the population of a given geographical area during a given year, per 1,000 mid-year total population of the given geographical area during the same year, thus expressed in per mille (Jurcova, 2005). In 2015, 53,826 people died in Slovakia; the crude death rate was $\mathbf{9 . 9 \%}$. Since 1993 , it has been below the level of 10 deceased per 1,000 people (Katusa et al., 2014).

Mortality is higher in men than in women (1,041 deceased men per 1,000 deceased 
women). The phenomenon of "over-mortality" of men is confirmed by the fact that $79 \%$ of all deaths in 2015 in the age category from 30 to 34 years are deceases of men. "Over-mortality" of women does not begin until in the age category of 75 years, which is closely related to the higher share of women in these age categories (SU SR, 2016).

Other indicators of mortality are similarly adverse. According to the OECD (Organization for Economic Co-operation and Development) the age-standardized mortality rate for cardiovascular diseases and the age-standardized mortality rate for cancer (per 100,000 population), Slovakia ranks among the worst countries of OECD and other compared countries (OECD, 2015). As for mortality for ischemic heart diseases and cerebrovascular diseases, Slovakia is in the last position; in mortality for cancer we are on the third place from the bottom among the 34 countries of OECD, see Table 1.

\section{Increasing life expectancy}

Life expectancy (at birth and ages 40, 60,65 and 80) is the average number of years that a person at that age can be expected to live, assuming that age-specific mortality levels remain constant (Jurcova, 2005). The life expectancy expresses the probable number of years remaining in the life of an individual or class of persons determined statistically and reflects the effects of other factors such as the standard of health service; health policy; availability of medical services; state of prevention; etc. (Filadelfiova et Bodnarova, 2013).

In 2015, the life expectancy at birth was 73.03 years in men and 79.73 years in women ( $\breve{S} U$ SR, 2016). In 2014, life expectancy of a 65-year old man was 15.1 years, that of a 65-year old woman 19.1 years (Eurostat, 2016).

As for the values of life expectancy, Slovakia ranks to the worst countries of the $\mathrm{Eu}$ ropean Union. Table 2 compares the newest life expectances at birth and at the age of 65 of women and men in selected countries in 2014 (Eurostat, 2015). Life expectancy at the age of 65 is shorter for men from Bulgaria, Latvia, Lithuania, Hungary, Romania,

Table 1: Age standardized mortality per 100,000 population in selected countries (source - OECD Health statistics)

\begin{tabular}{|l|l|l|l|}
\hline & $\begin{array}{l}\text { Ischemic heart } \\
\text { disease mortality } \\
\mathbf{2 0 1 3}\end{array}$ & $\begin{array}{l}\text { Cerebrovascular } \\
\text { disease mortality } \\
\mathbf{2 0 1 3}\end{array}$ & $\begin{array}{l}\text { Cancer mortality } \\
\mathbf{2 0 1 3} \\
\text { or nearest year }\end{array}$ \\
\hline OECD Countries & 117 & 66 & 205.6 \\
\hline United States & 128 & 44 & 197.9 \\
\hline Japan & 35 & 54 & 179 \\
\hline Germany & 115 & 52 & 205 \\
\hline Switzerland & 82 & 37 & 204.8 \\
\hline Austria & 140 & 49 & 197.1 \\
\hline Poland & 106 & 86 & 234.2 \\
\hline Hungary & 297 & 118 & 286.3 \\
\hline Czech Rep. & 260 & 97 & 229.8 \\
\hline Slovakia & $\mathbf{4 0 4}$ & $\mathbf{1 3 7}$ & $\mathbf{2 4 7 . 2}$ \\
\hline
\end{tabular}


Serbia and Macedonia, and for women from Bulgaria, Latvia, Hungary, Romania, Montenegro, Macedonia, Albania and Serbia. Life expectancy in Slovakia is slowly increasing, nevertheless it remains among the lowest values among the countries of the European Union (Katusa et al., 2014). the healthy life years for three ages - at birth, at age 50 and at age 65 - the indicator being presented separately for men and women. It is calculated using mortality statistics and data on self-perceived activity limitations. Mortality data come from Eurostat's demographic database, while self-perceived

Table 2: Life expectancy at birth and at age 65 in selected European countries (source http://ec.europa.eu/eurostat)

\begin{tabular}{|l|l|l|l|l|}
\hline \multirow{2}{*}{$\mathbf{2 0 1 4}$} & $\begin{array}{l}\text { Life expectan- } \\
\text { cy at birth }\end{array}$ & $\begin{array}{l}\text { Life expectan- } \\
\text { cy at age 65 }\end{array}$ & $\begin{array}{l}\text { Life expectan- } \\
\text { cy at birth }\end{array}$ & $\begin{array}{l}\text { Life expectan- } \\
\text { cy at age 65 }\end{array}$ \\
\cline { 2 - 5 } & \multicolumn{2}{|l|}{ Men (in years) } & \multicolumn{1}{|l|}{ Women (in years) } \\
\hline EU 28 Countries & 78.1 & 18.2 & 83.6 & 21. \\
\hline Slovakia & $\mathbf{7 3 . 3}$ & $\mathbf{1 5 . 1}$ & $\mathbf{8 0 . 5}$ & $\mathbf{1 9 . 1}$ \\
\hline Czech Republic & 75.8 & 16.1 & 82 & 19.8 \\
\hline Poland & 73.7 & 15.9 & 81.7 & 20.4 \\
\hline Hungary & 72.3 & 14.6 & 79.4 & 21.7 \\
\hline Austria & $79 . .2$ & 18.5 & 84 & 21.8 \\
\hline Sweden & 80.4 & 18.9 & 84.2 & 21.6 \\
\hline Germany & 78.7 & 18.2 & 83.6 & 21.4 \\
\hline France & 79,5 & 19.7 & 86 & 24 \\
\hline United Kingdom & 79.5 & 18.8 & 83.2 & 21.3 \\
\hline Italy & 80.7 & 19.2 & 85.6 & 22.8 \\
\hline Spain & 80.4 & 19.3 & 86.2 & 23.5 \\
\hline
\end{tabular}

For comparisons of single countries, another indicator is preferred recently, the healthy life years (disability-free life expectancy). This indicator expresses the average number of years in a healthy condition (Jurcova, 2005). Eurostat defines life in a healthy condition as a state that the person does not suffer from severe problems and can execute common activities (Bodnarova, 2013, Eurostat, 2013). The Healthy Life Years (HLY) indicator measures the number of years that a person (at birth, at age 65) is still expected to live in a healthy condition. HLY is a health expectancy indicator which combines information on mortality and morbidity. Eurostat calculates information relating to activity limitations data come from a European health module that is integrated within the data collection EU statistics on income and living conditions (EU-SILC). HLY is derived from self-reported data so it is, to a certain extent, affected by respondent's subjective perception as well as by their social and cultural background. EU-SILC does not cover the institutionalized population, for example, people living in health and social care institutions who are more likely to face limitations than the population living in private households. It is therefore likely that, to some degree, this data source under-estimates the share of the population facing limitations (Eurostat, 2013, Meszaros, 2010). 
Table 3 shows the healthy life years at birth and at the age of 65 years in selected countries for men and women in 2014.
In this context it might be worth mentioning that this position is possibly influenced by an ambiguous understanding of the survey question (Piscova et al., 2015).

Table 3: Healthy life years at birth and at age 65 in selected European countries (source http://ec.europa.eu/eurostat)

\begin{tabular}{|l|l|l|l|l|}
\hline \multirow{2}{*}{2014} & $\begin{array}{l}\text { Healthy life } \\
\text { years at birth }\end{array}$ & $\begin{array}{l}\text { Healthy life } \\
\text { years at age 65 }\end{array}$ & $\begin{array}{l}\text { Healthy life } \\
\text { years at birth }\end{array}$ & $\begin{array}{l}\text { Healthy life } \\
\text { years at age 65 }\end{array}$ \\
\cline { 2 - 5 } & \multicolumn{2}{|l|}{ Men (in years) } & \multicolumn{2}{|l|}{ Women (in years) } \\
\hline EU 28 Countries & 61,4 & 8,6 & 61,8 & 8,6 \\
\hline Slovakia & $\mathbf{5 5 , 5}$ & $\mathbf{4 , 3}$ & $\mathbf{5 4 , 6}$ & $\mathbf{3 , 6}$ \\
\hline Czech Republic & 63,4 & 8,5 & 65 & 9,3 \\
\hline Poland & 59,8 & 7,5 & 62,7 & 8,1 \\
\hline Hungary & 58,9 & 6 & 60,8 & 6,1 \\
\hline Austria & 57,6 & 8,4 & 57,8 & 7,7 \\
\hline Sweden & 73,6 & 15,2 & 73,6 & 16,7 \\
\hline Germany & 56,4 & 6,8 & 56,5 & 6,7 \\
\hline France & 63,4 & 10,4 & 64,2 & 10,7 \\
\hline United Kingdom & 63,4 & 9,7 & 64,2 & 10,6 \\
\hline Italy & 62,5 & 7,8 & 62,3 & 7,3 \\
\hline Spain & 65 & 10,1 & 65 & 9,4 \\
\hline
\end{tabular}

In 2014, the healthy life years indicators at birth in Slovakia were 55.5 years for men and 54.6 years for women; which is $75.7 \%$ of the life expectancy for men and $67.8 \%$ of the life expectancy for women. This means that men in Slovakia live with chronical diseases on average one quarter and women one third of their lives. The healthy life years at 65 years are similar - a 65-year old Slovakian man survives healthy 4.2 years shorter and a women 5.7 years shorter than the inhabitants of the Czech Republic of the same age (Eurostat, 2013).

These data are the worst among all countries of the European Union, therefore some authors refer to this indicator as our Achille's Heel (Bodnarova, 2013). Other authors recommend a rather cautious approach to the analyses and ranks based on this indicator.

\section{Changes in the age structure}

Aging brings about changes in the age structure of people; a growing group population above 65 years of age. Table 4 shows how the percentages of single age groups developed in 2001, 2006, 2010 and 2015.

At present, in Slovakia $\mathbf{1 4 . 4 5 \%}$ of inhabitants are 65 years old or older. Prognoses claim that during the next decades this group will grow 2.5-times in comparison with 2011. This means that in 2060 every third inhabitant of Slovakia will be older than 65 (Bleha et al., 2013). 
Table 4: Age structure of population in Slovakia in 2001, 2006, 2010, 2015

(source: Statistical Office of the Slovak Republic, 2016)

\begin{tabular}{|l|l|l|l|l|l|}
\hline Age group & $\mathbf{2 0 0 1}$ & $\mathbf{2 0 0 6}$ & & $\mathbf{2 0 1 0}$ & $\mathbf{2 0 1 5}$ \\
\hline $\mathbf{0}-\mathbf{1 4}$ years & $18.72 \%$ & $16.14 \%$ & & $15.28 \%$ & $15.33 \%$ \\
\hline $\mathbf{1 5}-\mathbf{6 4}$ years & $69.89 \%$ & $72 \%$ & & $72.34 \%$ & $70.22 \%$ \\
\hline $\mathbf{6 5}+$ years & $11.39 \%$ & $11.86 \%$ & & $12.38 \%$ & $14.45 \%$ \\
\hline
\end{tabular}

\section{Double aging}

Another important demographic feature is the growth of the group of "very old people" ("oldest old", above 80 years) (Hegyi et al., 2012), thus the so-called double aging. In 2012, people above 80 years created $15.4 \%$ of the group above 60 years and $22.7 \%$ of the group above 65 years (Katusa et al., 2014). Double aging will have an immense economic, social and medical importance (Weber, 2005).

\section{Feminization of aging}

The term feminization of aging is used to describe the increasing numbers of women in the older population. The feminity index (women-to-men ratio) is increasing (Hegyi et Krajcik, 2010).

More boys are born than girls $(1,049$ boys per 1,000 girls). This ratio is balanced around 45 years of age. At 60 years, the women-to-men ratio is 1,000:610, at 85 years the ratio is 2,600:1,000 and in the group above 90 years the ratio is 3:1 (Katusa et al., 2014).

This phenomenon is a two-edged sword - on the one hand it is a victory for women in overcoming mortality, on the other hand for many old women a period of social isolation and frequently economic adversity. The share of widows in the group above 80 years of age is $81.5 \%$ (Hegyi et al., 2012).

\section{Demographic indices}

In demography, important demographic indices related to seniors are utilized. They include:

\section{Aging index}

The aging index is calculated as the number of persons 60 years old or over per hundred persons under age 15, thus the ratio of the post-active component to the children's component. Since 1950, this index has continually increased. In 2013, there were 88.3 seniors per 100 children (while as many as 112 women per 100 girls) (National Program of Active Aging 2014; Katusa et al., 2014). According to prognoses, in 2060 this ratio will achieve a value of 220 , which means a three-fold growth in comparison with the year 2012 (Bleha et al., 2013).

\section{Total dependency ratio}

The total dependency ratio is the number of persons under age 15 plus persons aged 65 or older per one hundred persons between 15 to 64 years. The ratio determines the number of dependent people (children and seniors) per one hundred economically active people. Since 2009, its increase has been observed. In 2013, there were 40.57 dependent people per 100 productive persons (Katusa et al., 2014). Both of the indices are shown in Table 5.

The Active Aging Index (AAI) is constructed on the basis of four distinct domains

- employment,

- participation in society,

- independent, healthy and secure living,

- capacity and enabling environment for active aging. 
Table 5: Aging index and total dependency ratio in Slovakia (years 2003, 2007, 2010, 2015) Source: (Statistical Office of the Slovak Republic, 2016).

\begin{tabular}{|l|l|l|l|l|l|}
\hline \multicolumn{2}{|c|}{} & $\mathbf{2 0 0 3}$ & $\mathbf{2 0 0 7}$ & $\mathbf{2 0 1 0}$ & $\mathbf{2 0 1 5}$ \\
\hline \multirow{4}{*}{ Aging Index } & Men & 48,10 & 55,25 & 59,00 & 71,06 \\
\cline { 2 - 6 } & Women & 84,20 & 97,83 & 104,07 & 118,62 \\
\cline { 2 - 6 } & All & 65,70 & 76,00 & 81,01 & 94,22 \\
\hline Total dependency ratio & All & 41,01 & 38,38 & 38,23 & 42,41 \\
\hline
\end{tabular}

The four domains are populated by a set of 22 indicators. AAI score for individual countries shows the extent to which their old people's potential is used; and the extent to which older people are enabled and encouraged to participate in the economy and society. The theoretical maximum is 100 . The latest 2014 AAI results of the EU28 are presented in Figure 1. The highest 2014 AAI score stands at 44.8 points (Sweden). Slovakia is on the third place from the bottom (score 28.5), leaving behind only Poland (score 28.2) and Greece (score 27.7) (UNECE, 2014).

One of the main issues for the future development of the Slovak Society is the process of population aging (Sprocha, 2015). Population aging is caused by the improvements in the health service; by changes in the reproduction behavior of the population; by the longer lives of individuals (Katusa et al., 2014). It is valid generally that in the countries in which the process of population aging began later (Slovakia belongs to this group) this process is more intense and these countries will have less time for accommodation. Therefore, the statistical data should be used to identify and measure the possible consequences of this process and to mitigate them. If the society is not prepared for these severe issues, the way of organization and control of the society will change dramatically. Substantial changes will occur in the economy; on the labor market; in the pension system; in the health service; etc. (Katusa et al., 2014; National program of Active Aging 2014).

\section{References}

1. ACTIVE AGEING INDEX FOR 28 EUROPEAN UNION COUNTRIES (2014) (online). EC; UNECE (cit. 1. 8. 2015). Available from: <http://www.unece.org/ fileadmin/DAM/pau/age/WG7/Documents/ Policy_Brief_AAI_for_EG_v2.pdf $>$.

2. BLEHA B, SPROCHA B, VANO B (2013) Prognosis of population development in Slovak Republic until year 2060. Bratislava: Infostat, 2013, 81 p. ISBN 978-80-89398-23-2.

3. BODNAROVA B (2013) Health and Age: For Healthier ageing. In: The Fourth Dimension of the Third Age. Ten Chapters on Active Ageing. [Butorova, Z. a kol. - eds.]. Bratislava : IVO, 2013, p. 61-94. ISBN 978-80-89345-44-1.

4. EUROSTAT (2014) Healthy life years statistics. [online]. [cited 19.10.2014] Available at: http://ec.europa.eu/eurostat/statistics-explained/index.php/Healthy_life_years_statistics

5. FILADELFIOVA J, BODNAROVA B (2013) Facts that won't let go: how does Slovakia's population age. In: The Fourth Dimension of the Third Age. Ten Chapters on Active Ageing. [Butorova, Z. a kol. - eds.]. Bratislava : IVO, 2013, p. 45-59. ISBN 978-80-89345-44-1.

6. HEGYI L, KRAJCIK S (2010) Geriatrics. 1. vyd. Bratislava: Herba, 2010, 608 p. ISBN 978-80-89171-73-6.

7. HEGYI L et al (2012) Social gerontology. 1 vyd. Bratislava: Herba, 2012, 172 p. ISBN 978-80-89171-99-6. 
8. JURCOVA D (2005) Dictionary of demographic terms. Bratislava: Infostat, 2005, 72 p. ISBN 80-85659-40-9.

9. KATUSA M et al (2013) The development of the population in the Slovak republic and regions in 2013. Bratislava: Statistical Office of the Slovak Republic, 2014, 150 p. ISBN 978-80-8121-309-0.

10. MESZAROS J (2009) Healthy life years according to EHIS 2009. Bratislava: Infostat, 2010, $34 \mathrm{p}$.

11. NATIONAL PROGRAM OF ACTIVE AGEING FOR THE YEARS 2014-2020 (2014) Bratislava: Ministry of labour, social affairs and family, 2014, 83 p. ISBN 97880-89125-18-0.

12. OECD (2015) Health at a glance. OECD indicators. OECD: 2015. [online]. [cited 7.5.2016] DOI: 10.1787/health_glance-2015en. Available na: http://www.oecd.org/els/ health-systems/Health-at-a-Glance-2013.pdf.

13. PISCOVA M, KLOBUCKY R, BAHNA M (2015) Elderly people in society and in family.
Several Views on Elderly People in Statistics and Comparative Surveys Data. Slovak statistics and demography 2015; 25 (3): p. 22-43.

14. STATISTICAL OFFICE OF THE SLOVAK REPUBLIC (2016) Demographical processes in the Slovak Republic 2015. Bratislava: 2016. [online]. [cited 12.5.2016] Available at: https://slovak.statistics.sk/wps/ wcm/connect/932219bf-d5bf-4607-96eb0a5ea1528cbf/Demograficke_procesy_v_ SR_rok_2015.pdf?MOD=AJPERES.

15. SPROCHA B (2015) The age structure of the population in the Slovak Republic and in regions and its projection up to 2030. Slovak statistics and demography 2015; 25 (3): p. 7-21.

16. VANO B (2015) Editorial. Slovak statistics and demography 2015; 25 (3): p. 1-4.

17. WEBER P (2005) Basics of gerontology and geriatrics. In: P. Dítě (ed.): Internal medicine III - skriptum. Brno: School of Medicine MU, 2005, p. 675 - 689 s. ISBN 80-210-3673-7.

Figure 1: Ranking of 28 EU Member States on the basis of the 2014 Active Aging Index (source: <http://www.unece.org/fileadmin/DAM/pau/age/WG7/Documents/Policy_ Brief_AAl_for_EG_v2.pdf>.

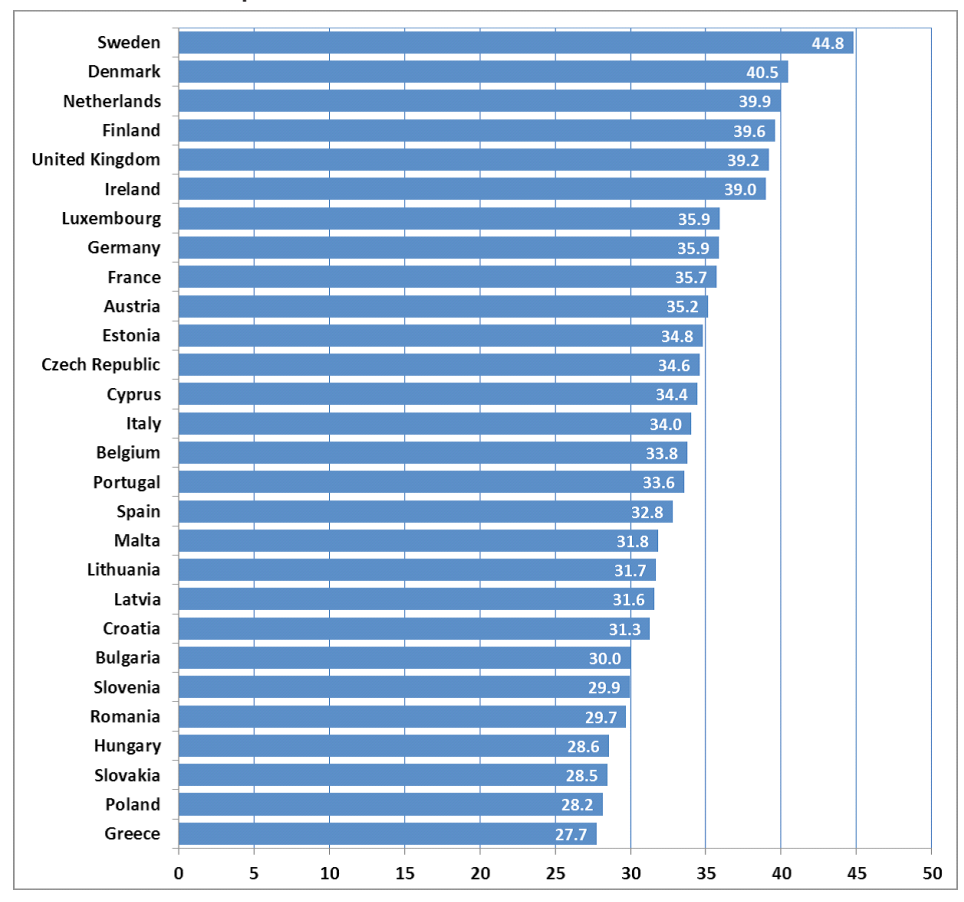

